\title{
Yield formation and quality characteristics of early potatoes during a short growing period
}

\author{
Leo Mustonen \\ MTT Agrifood Research Finland, Plant Production Research, FI-31600 Jokioinen, Finland, \\ e-mail:leo.mustonen@mtt.fi
}

\begin{abstract}
The effects of nitrogen fertilization on the yield and quality of early potato (Solanum tuberosum L.) were studied at MTT Agrifood Research Finland during 1996-1997. Cultivars were harvested at three times. The experimental layout was a split-split-plot with harvest times as main plots and nitrogen fertilization and potato cultivars as the subplots. The fertilizer treatments were 60 and $120 \mathrm{~kg} \mathrm{~N} \mathrm{ha}^{-1}$ and the cultivars tested were Timo, Gloria and Van Gogh. The harvest times were 57-62, 70-75 and 85-90 days after planting. Application of $120 \mathrm{~kg} \mathrm{~N} \mathrm{ha}^{-1}$ intensified canopy development and increased leaf area of the stands. At early harvest the tuber yield of all cultivars receiving the higher nitrogen application increased by $0.5-2.5 \mathrm{t} \mathrm{ha}^{-1}$. The highest yielding cultivar was Timo. At last harvest, the higher nitrogen treatment increased yield by 3.0-6.2 $\mathrm{t} \mathrm{ha}^{-1}$. The highest yielding cultivars were Timo and Van Gogh. The dry matter content of tubers was very low, 13.8-17.2\%, at the first harvest and the higher nitrogen application reduced dry matter content by $0.3-1.0 \%$. The highest fertilizer application rate resulted in the largest tuber size. Nitrogen application, however, affected the quality of potatoes by decreasing the dry matter content. The nitrate content in tubers increased significantly with the increasing level of nitrogen. The range of nitrate content in tubers fluctuated between 13 and $189 \mathrm{mg} \mathrm{kg}^{-1}$ fresh weight showing good controlling of nitrate values. Harvest time affected sucrose content and the reducing sugar content in tubers, but nitrogen fertilizer did not change the sugar content of tubers. As tuber yield and quality during a short growing season are affected mainly by intercepted radiation, methods to increase tuber yield should focus on reducing the time to emergence, improving haulm growth after emergence and increasing the harvest index.
\end{abstract}

Key words: yields, early potato, nitrates, nitrogen fertilizers, cultivars, sugar content

\section{Introduction}

Early potatoes (Solanum tuberosum L.) with unset skins represent an important market in Finland.
The first early season, when potatoes are lifted at a low yield, extends from the end of June to the end of July and second early production covers the period to the end of August. The main growing areas are those of the southwest coast of Finland, where 
Vol. 13 (2004): 390-398.

it is usual that most potatoes are lifted before mid July. The growing period for early potatoes is extremely short; only 50-80 days from planting to harvest.

The objectives of nitrogen management of a potato crop are to optimise the use of plant resources and minimise risk of disadvantageous environmental effects related to leaching of excess nitrogen. In early low yield potato production nitrogen supply greatly affects yield and the quality of tubers. During early growth stages excess nitrogen causes overproduction of foliage, resulting in sub-optimal yield and early development (Biemond and Vos 1992). Large amounts of nitrogen will only be used effectively if the crop is allowed to develop to maturity (Vos and Biemond 1992, O'Brien et al. 1998). A review by O'Brien et al. (1998) concluded that there was not much evidence that nitrogen affected tuber initiation and that only excessive amounts of nitrogen delayed it. An optimal nitrogen supply ensures continued growth and a yield level close to potential yield, while minimising losses of nitrogen to the environment. Therefore, the application of nitrogen fertilizer must be set according to the potential yield of the crop and the intended harvest date.

Tuber quality is at its highest when the nitrogen supply matches the requirement of the crop over the length of the growing season. High rates of nitrogen application will delay the amount of dry matter transferred to tubers and decrease their dry matter content (Vos and Biemond 1992, Vos 1997). In early potato production, when tubers are harvested at low yield, low dry matter content creates a soggy texture and decreases potato quality. Under conditions of increased nitrogen supply the potato crop has the ability to take up nitrogen in excess to that required for growth and store it as nitrate in the vacuoles (Millard and Marshall 1986). Potato tubers normally have low nitrate content, not exceeding $300 \mathrm{mg} \mathrm{kg}^{-1}$ in fresh matter (Blom-Zandstra 1989). The nitrate content of the tubers depends on cultivar, availability of nitrogen during tuber growth and environmental factors. However, large differences (e.g. 30-300 mg kg-1) may occur, and early cultivars generally have higher contents compared with late ones (Wust- man et al. 1996). The sugar content of tubers has been shown to be affected by cultivar, maturity and nitrogen supply to the crop. Tubers harvested early have high reducing sugar content, which affects the aroma and the quality of early potatoes.

The objective of this study was to monitor the effect of nitrogen application on the yield and quality of early potatoes at the first early harvest during late June and the second early harvest up to early August. A compromise between acceptable yield level and satisfactory quality characteristics was sought.

\section{Material and methods}

Field experiments were carried out at MTT Agrifood Research Finland, Plant Production Research, Jokioinen $\left(61^{\circ} 06^{\prime} \mathrm{N}, 23^{\circ} 02^{\prime}\right)$ in $1996-1997$. The experimental layout was a split-split-plot design of four replicate blocks. Harvest times where arranged in main plots and nitrogen fertilization and potato cultivars in the subplots. The fertilizer treatments were 60 and $120 \mathrm{~kg} \mathrm{~N} \mathrm{ha}^{-1}$. The cultivars tested were first early cultivar Timo and second early cultivar Gloria and early main cultivar Van Gogh. Soil was classified as fine sandy loam, representative of soils for potato cultivation in Finland.

The basal fertilizer dressing was $60 \mathrm{~kg} \mathrm{ha}^{-1}$ and $120 \mathrm{~kg} \mathrm{~N} \mathrm{ha}{ }^{-1}$ (ammonium nitrate limestone, 27.5\% N, Kemira Agro Oy, Finland) applied at planting and placed in two rows $5 \mathrm{~cm}$ beneath and $10 \mathrm{~cm}$ to the side of seed tubers. Potassium sulphate $(42 \% \mathrm{~K})$ and superphosphate $(9 \% \mathrm{P})$ were broadcast on the soil before planting in accordance with the information from soil analysis and local recommendations. The trial field was ploughed in the autumn and prepared for planting by harrowing to $15 \mathrm{~cm}$ in the spring.

A subplot consisted of two rows of $0.75 \times 6.0$ $\mathrm{m}$, with a harvested net plot size of $7.5 \mathrm{~m}^{2}$. Seed tubers were presprouted for four weeks in light at $12-15^{\circ} \mathrm{C}$. The seed potato was certified seed grade $45-50 \mathrm{~mm}$. Seed was spaced $25 \mathrm{~cm}$ apart with up- 
per surface $5 \mathrm{~cm}$ below the soil using a semiautomatic planter on 9 May 1996 and 12 May 1997. Mean soil temperature at planting was about 6$8^{\circ} \mathrm{C}$. The trials were grown under fleece, as commonly used in first early potato production. The fleece was removed two weeks after crop emergence. Weeds were controlled chemically before plant emergence and one inter-row cultivation was done 7 days after emergence to control weeds and to earth-up plots. One protective spraying to control foliage blight was made according to the local plant protection practice for the second harvest and two sprayings for the third harvest. Trials were harvested with a tractor-mounted single row harvester without prior haulm killing. Trials where harvested 60 days after planting (DAP) (Harvest 1), 74 DAP (Harvest 2) and 88 DAP (Harvest 3). Weather data for May - August were from the Jokioinen weather station of the Finnish Meteorological Institute, which is situated $5 \mathrm{~km}$ from the experimental fields. These are given in Table 1.

Emergence was recorded three times a week and the number of days to $75 \%$ emergence was estimated using linear interpolation. Crop analysis during growth included estimation of foliar leaf area index (LAI), which was recorded 55-57 DAP with an automatic LAI meter (Licor Inc, USA). After harvest, tubers were graded according to size: $<30 \mathrm{~mm}, 35-50 \mathrm{~mm}$ and $>50 \mathrm{~mm}$. Before grading, a $3 \mathrm{~kg}$ tuber sample per plot was taken for dry matter determination and for analysis of nitrate and sugar content.

Table 1. Deviation from long-term (1970-1995) monthly mean temperature $\left({ }^{\circ} \mathrm{C}\right)$ and precipitation $(\mathrm{mm})$ at Jokioinen Meteorological Station in 1996 and 1997.

\begin{tabular}{lrrrr}
\hline & May & June & July & August \\
\hline Mean temperature $\left({ }^{\circ} \mathrm{C}\right)$ & & & & \\
$1970-1995$ & 9.7 & 14.1 & 16.1 & 14.3 \\
1996 & -0.9 & -1.0 & -2.2 & +2.7 \\
1997 & -2.0 & +2.0 & +1.7 & +3.5 \\
Precipitation (mm) & & & & \\
$1970-1995$ & 35 & 56 & 82 & 86 \\
1996 & +30 & -4 & +54 & -62 \\
1997 & -19 & +45 & -59 & -39 \\
\hline
\end{tabular}

For determination of dry matter content, a sample of 10-15 tubers was sliced to facilitate drying at $60^{\circ} \mathrm{C}$ for 48 hours. The nitrate content was analysed from fresh potato tubers with a nitrate electrode (ORION 1983, Aura 1985). The extraction method described by Haila et al. (1992) was applied for analysis of sugars and organic acids. Derivatization of sugars was performed using the method of Li and Schuhman (1980). The derivates were identified and quantified using a gas chromatograph equipped with flame ionisation detector. Reference compounds and the international standard were analysed parallel to the samples to identify and quantify the peaks produced by the samples.

Response variables of the data for two years were analysed using repeated measures analysis of variance, with time of harvest as a repeated factor. PROC MIXED (Littell et al. 1996) of SAS/STAT software was used. The mixed models were fitted using the residual maximum likelihood (REML). Before analyses, the distributional assumptions of the models were checked graphically. The residuals were checked for normality using box plots (Tukey 1977). Differences at $\mathrm{P} \leq 0.05$ among least significant means were established using $\mathrm{CON}$ TRAST statements in PROC MIXED.

\section{Results}

The period from planting to $75 \%$ emergence differed among years $(P=0.001)$ whereas no difference was detected between the effect of nitrogen application levels $(\mathrm{P}=0.537)$ or cultivars $(\mathrm{P}=$ 0.517). Number of days to emergence ranged from 21 days in 1997 to 25 days in 1996 (Table 2). LAI recorded 25 DAP showed significant difference among nitrogen fertilization levels $(\mathrm{P}=0.001)$, testing years $(\mathrm{P}=0.012)$ and cultivars $(\mathrm{P}=0.001)$. Number of main stems and number of tubers per hill were very balanced and did not differ among years, nitrogen levels or cultivars (Table 2).

Analysis of yield data indicated that nitrogen application significantly affected tuber yield $(\mathrm{P}<$ 
Vol. 13 (2004): 390-398.

0.001). Nitrogen had a similar effect in both trial years $(\mathrm{P}<0.443)$, but there was a difference in response among harvest dates $(\mathrm{P}<0.001)$. At first early harvest nitrogen applied at $120 \mathrm{~kg} \mathrm{ha}^{-1}$ increased tuber yield by $0.5-2.5 \mathrm{t} \mathrm{ha}^{-1}$, at second early harvest by $0.7-3.4 \mathrm{t} \mathrm{ha}^{-1}$ and at early August harvest by 3.0-6.2 $\mathrm{t} \mathrm{ha}^{-1}$ (Table 4). Cultivars differed significantly in tuber yield $(\mathrm{P}<0.001)$ and reacted differently in trial years $(\mathrm{P}<0.001)$ and according to harvest date $(\mathrm{P}<0.021)$. All three cultivars reacted similarly to nitrogen application rates $(\mathrm{P}<0.695)$. The second order interactions, year $\times$ nitrogen $\times$ cultivar $(\mathrm{P}<0.561)$ and harvest date $\times$ nitrogen $\times$ cultivar $(\mathrm{P}<0.308)$ were not statistically significant and indicated the balanced effect of nitrogen under different conditions. The highest yielding cultivar at first early harvest date was Timo at $14.1 \mathrm{t} \mathrm{ha}^{-1}$ and at the last harvest date Timo at $29.7 \mathrm{t} \mathrm{ha}^{-1}$ and Van Gogh at $27.6 \mathrm{t} \mathrm{ha}^{-1}$ (Table 4). Nitrogen applied at $120 \mathrm{~kg} \mathrm{ha}^{-1} \mathrm{de}-$ creased the proportion of small grade tubers $(<35$ $\mathrm{mm})$ significantly $(\mathrm{P}<0.001)$ and increased the proportion of large grades $(>50 \mathrm{~mm})$ significantly $(\mathrm{P}<0.001)$. The effect of nitrogen on proportion of small tubers $(<35 \mathrm{~mm})$ was also affected by trial year $(\mathrm{P}<0.001)$ and cultivar $(\mathrm{P}<0.001)$. The effect of nitrogen fertilization on tuber size was more pronounced in 1997 than in 1996. Timo had clearly the largest tubers at first early harvest (Table 3).

Dry matter content of tubers was affected by nitrogen fertilizer application $(\mathrm{P}<0.001)$, years $(\mathrm{P}$

Table 2. Effect of nitrogen rate and cultivar on emergency, leaf area index, number of stems and number of tubers in 1996-1997. Means within each year and treatment not followed by same letter are significantly different at $\mathrm{P} \leq 0.05$.

\begin{tabular}{|c|c|c|c|c|c|c|c|c|}
\hline \multirow[t]{2}{*}{ Treatment } & \multicolumn{2}{|c|}{ Emergence (d) } & \multicolumn{2}{|c|}{ Leaf area index } & \multicolumn{2}{|c|}{ Number of stems } & \multicolumn{2}{|c|}{ Number of tubers } \\
\hline & 1996 & 1997 & 1996 & 1997 & 1996 & 1997 & 1996 & 1997 \\
\hline \multicolumn{9}{|l|}{$\mathrm{kg} \mathrm{N} \mathrm{ha}^{-1}$} \\
\hline 60 & $24 \mathrm{a}$ & $22 \mathrm{a}$ & $2.5 \mathrm{a}$ & $2.9 \mathrm{a}$ & $3.0 \mathrm{a}$ & $2.8 \mathrm{a}$ & $6.9 \mathrm{a}$ & $7.7 \mathrm{a}$ \\
\hline 120 & $24 \mathrm{a}$ & $22 \mathrm{a}$ & $2.9 \mathrm{~b}$ & $3.3 \mathrm{~b}$ & $2.8 \mathrm{a}$ & $2.8 \mathrm{a}$ & $7.3 \mathrm{a}$ & $7.6 \mathrm{a}$ \\
\hline \multicolumn{9}{|l|}{ Cultivar } \\
\hline Timo & $25 \mathrm{a}$ & $21 \mathrm{a}$ & $3.2 \mathrm{a}$ & $3.5 \mathrm{a}$ & $3.6 \mathrm{a}$ & $2.7 \mathrm{a}$ & $7.0 \mathrm{a}$ & $7.9 \mathrm{a}$ \\
\hline Gloria & $24 \mathrm{~b}$ & $22 \mathrm{a}$ & $2.4 \mathrm{~b}$ & $2.6 \mathrm{c}$ & $2.8 \mathrm{a}$ & $3.2 \mathrm{a}$ & $7.1 \mathrm{a}$ & $7.1 \mathrm{a}$ \\
\hline Van Gogh & $24 \mathrm{~b}$ & $23 \mathrm{a}$ & $2.5 \mathrm{~b}$ & $3.1 \mathrm{~b}$ & $2.4 \mathrm{a}$ & $2.5 \mathrm{a}$ & $7.1 \mathrm{a}$ & $7.9 \mathrm{a}$ \\
\hline
\end{tabular}

Table 3. Effect of year, nitrogen rate and cultivar on tuber yield, dry matter content, size distribution and nitrate content in 1996-1997. Means within each year and treatment not followed by same letter are significantly different at $\mathrm{P} \leq 0.05$.

\begin{tabular}{|c|c|c|c|c|c|c|c|c|c|}
\hline \multirow[t]{2}{*}{ Treatment } & \multicolumn{2}{|c|}{$\begin{array}{c}\text { Tuber yield } \\
\left(\mathrm{t} \mathrm{ha}^{-1}\right)\end{array}$} & \multicolumn{2}{|c|}{$\begin{array}{c}\text { Dry matter } \\
(\%)\end{array}$} & \multicolumn{3}{|c|}{ Tuber size $(\mathrm{mm})$} & \multicolumn{2}{|c|}{$\begin{array}{c}\text { Nitrate } \\
\left(\mathrm{mg} \mathrm{kg}^{-1}\right) \text { fresh weight }\end{array}$} \\
\hline & 1996 & 1997 & 1996 & 1997 & $<35$ & $35-50$ & $>50$ & 1996 & 1997 \\
\hline \multicolumn{10}{|l|}{ Harvest time } \\
\hline I & $11.7 \mathrm{a}$ & $12.1 \mathrm{a}$ & $14.3 \mathrm{a}$ & $16.2 \mathrm{a}$ & $17.4 \mathrm{a}$ & $80.5 \mathrm{a}$ & $2.1 \mathrm{a}$ & $120.7 \mathrm{a}$ & $47.9 \mathrm{a}$ \\
\hline II & $21.7 \mathrm{~b}$ & $19.4 \mathrm{~b}$ & $18.3 \mathrm{~b}$ & $21.8 \mathrm{~b}$ & $14.3 \mathrm{~b}$ & $80.9 \mathrm{a}$ & $4.8 \mathrm{~b}$ & $70.3 \mathrm{~b}$ & $35.9 \mathrm{~b}$ \\
\hline III & $29.1 \mathrm{c}$ & $24.8 \mathrm{c}$ & $21.2 \mathrm{c}$ & $20.7 \mathrm{c}$ & $5.3 \mathrm{c}$ & $74.3 \mathrm{~b}$ & $20.4 \mathrm{c}$ & $49.6 \mathrm{c}$ & $47.0 \mathrm{a}$ \\
\hline \multicolumn{10}{|l|}{$\mathrm{kg} \mathrm{N} \mathrm{ha}^{-1}$} \\
\hline 60 & $19.2 \mathrm{a}$ & $17.4 \mathrm{a}$ & $18.3 \mathrm{a}$ & $19.8 \mathrm{a}$ & $13.3 \mathrm{a}$ & $79.0 \mathrm{a}$ & $7.7 \mathrm{a}$ & $60.6 \mathrm{a}$ & $36.4 \mathrm{a}$ \\
\hline 120 & $22.4 \mathrm{~b}$ & $20.2 \mathrm{~b}$ & $17.6 \mathrm{~b}$ & $19.3 \mathrm{~b}$ & $11.4 \mathrm{a}$ & $78.1 \mathrm{a}$ & $10.5 \mathrm{~b}$ & $99.8 \mathrm{~b}$ & $50.8 \mathrm{~b}$ \\
\hline \multicolumn{10}{|l|}{ Cultivar } \\
\hline Timo & $22.4 \mathrm{a}$ & $22.2 \mathrm{a}$ & $17.4 \mathrm{a}$ & $19.1 \mathrm{a}$ & $6.3 \mathrm{a}$ & $75.2 \mathrm{a}$ & $18.5 \mathrm{a}$ & $87.5 \mathrm{a}$ & $44.5 \mathrm{a}$ \\
\hline Gloria & $18.2 \mathrm{~b}$ & $16.1 \mathrm{~b}$ & $18.0 \mathrm{~b}$ & $19.5 \mathrm{~b}$ & $15.4 \mathrm{~b}$ & $79.1 \mathrm{~b}$ & $5.5 \mathrm{~b}$ & $90.4 \mathrm{a}$ & $43.0 \mathrm{a}$ \\
\hline Van Gogh & $21.9 \mathrm{a}$ & $18.1 \mathrm{c}$ & $18.5 \mathrm{c}$ & $20.1 \mathrm{c}$ & $15.2 \mathrm{~b}$ & $81.4 \mathrm{c}$ & $3.4 \mathrm{c}$ & $62.7 \mathrm{~b}$ & $43.3 \mathrm{a}$ \\
\hline
\end{tabular}


Mustonen, L. Yield formation of early potatoes during a short growing period

Table 4. Effect of year, harvesting time, cultivar and nitrogen rate on tuber yield ( $\left.\mathrm{tha}^{-1}\right)$ in 1996-1997. Means within each year and treatment not followed by same letter are significantly different at $\mathrm{P} \leq 0.05$.

\begin{tabular}{|c|c|c|c|c|c|c|}
\hline \multirow{3}{*}{ Treatment } & \multicolumn{3}{|c|}{1996} & \multicolumn{3}{|c|}{1997} \\
\hline & \multicolumn{3}{|c|}{ Harvest time } & \multicolumn{3}{|c|}{ Harvest time } \\
\hline & I & II & III & I & II & III \\
\hline Timo $\mathrm{N}_{60}$ & $12.7 \mathrm{a}$ & $20.8 \mathrm{a}$ & $28.8 \mathrm{a}$ & $13.7 \mathrm{a}$ & $22.6 \mathrm{a}$ & $24.5 \mathrm{a}$ \\
\hline Timo $\mathrm{N}_{120}$ & $13.7 \mathrm{a}$ & $24.2 \mathrm{~b}$ & $34.1 \mathrm{~b}$ & $16.2 \mathrm{~b}$ & $24.5 \mathrm{a}$ & $30.7 \mathrm{~b}$ \\
\hline Gloria $\mathrm{N}_{60}$ & $9.0 \mathrm{a}$ & $17.5 \mathrm{a}$ & $23.9 \mathrm{a}$ & $9.5 \mathrm{a}$ & $15.2 \mathrm{a}$ & $19.4 \mathrm{a}$ \\
\hline Gloria $\mathrm{N}_{120}$ & $9.5 \mathrm{a}$ & $20.9 \mathrm{~b}$ & $28.2 \mathrm{~b}$ & $11.7 \mathrm{~b}$ & $18.2 \mathrm{~b}$ & $22.4 \mathrm{~b}$ \\
\hline Van Gogh $\mathrm{N}_{60}$ & $11.6 \mathrm{a}$ & $21.8 \mathrm{a}$ & $27.0 \mathrm{a}$ & $9.8 \mathrm{a}$ & $17.6 \mathrm{a}$ & $23.1 \mathrm{a}$ \\
\hline Van Gogh $N_{120}$ & $13.7 \mathrm{~b}$ & $24.9 \mathrm{~b}$ & $32.5 \mathrm{~b}$ & $11.6 \mathrm{a}$ & $18.3 \mathrm{a}$ & $27.9 \mathrm{~b}$ \\
\hline
\end{tabular}

$<0.001)$, cultivars $(\mathrm{P}<0.001)$ and particularly between harvest dates $(\mathrm{P}<0.001)$. There was also a significant nitrogen $\times$ cultivar interaction $(\mathrm{P}<$ $0.001)$ but interactions between nitrogen, year $(\mathrm{P}<$ $0.451)$ and harvest time $(\mathrm{P}<0.414)$ were not significant. At first and second early harvest the high nitrogen application decreased dry matter content of tubers by $0.2-1.0 \%$ and at last harvest by $0.1-$ $1.8 \%$. At first early harvest dry matter content of tubers was very low (13.8-17.2\%) and the high nitrogen application produced the lowest dry matter content (13.8\%) in cultivar Timo (Table 5).

Nitrogen application rate $(\mathrm{P}<0.001)$, cultivar $(\mathrm{P}<0.001)$ and particularly year $(\mathrm{P}<0.001)$ had significant effects on nitrate content of potatoes.
Also cultivars reacted differently to nitrogen ( $\mathrm{P}<$ $0.001)$ and the reaction of cultivars across the years $(\mathrm{P}<0.001)$ and harvesting dates $(\mathrm{P}<0.001)$ differed significantly. At first early harvest in 1996 the concentration of nitrate at $120 \mathrm{~kg} \mathrm{~N} \mathrm{ha}^{-1}$ ranged from 106-189 $\mathrm{mg} \mathrm{NO}_{3}$ fresh weight. Application at $60 \mathrm{~kg} \mathrm{~N} \mathrm{ha}^{-1}$ produced a low rate of nitrate accumulation, averaging $96 \mathrm{mg} \mathrm{NO}_{3}$ fresh weight in 1996 and $43 \mathrm{mg} \mathrm{NO}_{3}$ fresh weight in 1997 (Table 6 ). The highest nitrate values were found in the early cultivars Timo and Gloria (Table 3).

The harvest date, cultivar and trial year had very significant effects on sucrose and the contents of reducing sugars, glucose and fructose, whereas no differences in glucose $(\mathrm{P}<0.919)$, fructose $(\mathrm{P}<$

Table 5. Effect of year, harvesting time, cultivar and nitrogen rate on dry matter content (\%) in 1996-1997. Means within each year and treatment not followed by same letter are significantly different at $\mathrm{P} \leq 0.05$.

\begin{tabular}{|c|c|c|c|c|c|c|}
\hline \multirow{3}{*}{ Treatment } & \multicolumn{3}{|c|}{1996} & \multicolumn{3}{|c|}{1997} \\
\hline & \multicolumn{3}{|c|}{ Harvest time } & \multicolumn{3}{|c|}{ Harvest time } \\
\hline & I & II & III & I & II & III \\
\hline Timo $\mathrm{N}_{60}$ & $14.3 \mathrm{a}$ & $18.4 \mathrm{a}$ & $21.3 \mathrm{a}$ & $16.0 \mathrm{a}$ & $22.8 \mathrm{a}$ & $19.4 \mathrm{a}$ \\
\hline Timo $\mathrm{N}_{120}$ & $13.8 \mathrm{a}$ & $17.0 \mathrm{~b}$ & $19.5 \mathrm{~b}$ & $15.4 \mathrm{~b}$ & $21.6 \mathrm{~b}$ & $19.6 \mathrm{a}$ \\
\hline Gloria $\mathrm{N}_{60}$ & $14.7 \mathrm{a}$ & $17.9 \mathrm{a}$ & $23.3 \mathrm{a}$ & $17.2 \mathrm{a}$ & $21.1 \mathrm{a}$ & $21.2 \mathrm{a}$ \\
\hline Gloria $\mathrm{N}_{120}$ & $14.4 \mathrm{a}$ & $18.8 \mathrm{a}$ & $21.1 \mathrm{~b}$ & $16.2 \mathrm{~b}$ & 20.9 a & $20.3 \mathrm{~b}$ \\
\hline $\operatorname{Van}$ Gogh $\mathrm{N}_{60}$ & $14.7 \mathrm{a}$ & $19.8 \mathrm{a}$ & $21.1 \mathrm{a}$ & $16.4 \mathrm{a}$ & $22.3 \mathrm{a}$ & $22.0 \mathrm{a}$ \\
\hline Van Gogh $N_{120}$ & $13.9 \mathrm{~b}$ & $19.1 \mathrm{~b}$ & $22.2 \mathrm{~b}$ & $15.7 \mathrm{~b}$ & $22.0 \mathrm{a}$ & $21.9 \mathrm{a}$ \\
\hline
\end{tabular}


Vol. 13 (2004): 390-398.

Table 6. Effect of year, harvesting time, cultivar and nitrogen rate on nitrate content ( $\mathrm{mg} \mathrm{kg}^{-1}$, fresh weight) in 1996-1997. Means within each year and treatment not followed by same letter are significantly different at $\mathrm{P} \leq 0.05$.

\begin{tabular}{|c|c|c|c|c|c|c|}
\hline \multirow{3}{*}{ Treatment } & \multicolumn{3}{|c|}{1996} & \multicolumn{3}{|c|}{1997} \\
\hline & \multicolumn{3}{|c|}{ Harvest time } & \multicolumn{3}{|c|}{ Harvest time } \\
\hline & I & II & III & I & II & III \\
\hline Timo $\mathrm{N}_{60}$ & $138.9 \mathrm{a}$ & $45.5 \mathrm{a}$ & $42.1 \mathrm{a}$ & $57.2 \mathrm{a}$ & $13.1 \mathrm{a}$ & $47.5 \mathrm{a}$ \\
\hline Timo $N_{120}^{00}$ & $141.4 \mathrm{a}$ & $81.5 \mathrm{~b}$ & $75.7 \mathrm{~b}$ & $47.4 \mathrm{a}$ & $50.7 \mathrm{~b}$ & $51.4 \mathrm{a}$ \\
\hline Gloria $\mathrm{N}_{60}$ & $83.9 \mathrm{a}$ & $60.5 \mathrm{a}$ & $32.4 \mathrm{a}$ & $37.3 \mathrm{a}$ & $36.3 \mathrm{a}$ & $41.8 \mathrm{a}$ \\
\hline Gloria $\mathrm{N}_{120}$ & $188.7 \mathrm{~b}$ & $118.9 \mathrm{~b}$ & $57.8 \mathrm{a}$ & $60.6 \mathrm{~b}$ & $40.3 \mathrm{a}$ & $41.8 \mathrm{a}$ \\
\hline $\operatorname{Van}$ Gogh $\mathrm{N}_{60}$ & $65.7 \mathrm{a}$ & $30.5 \mathrm{a}$ & $45.7 \mathrm{a}$ & $20.0 \mathrm{a}$ & $36.9 \mathrm{a}$ & $37.8 \mathrm{a}$ \\
\hline Van Gogh $\mathrm{N}_{120}$ & $105.1 \mathrm{~b}$ & $85.1 \mathrm{~b}$ & $44.0 \mathrm{a}$ & $65.2 \mathrm{~b}$ & $38.3 \mathrm{a}$ & $61.7 \mathrm{~b}$ \\
\hline
\end{tabular}

Table 7. Effect of year, nitrogen rate and cultivar on sugar contents in 1996-1997. Means within each year and treatment not followed by same letter are significantly different at $\mathrm{P} \leq 0.05$.

\begin{tabular}{|c|c|c|c|c|c|c|c|c|}
\hline \multirow{3}{*}{ Treatment } & \multicolumn{6}{|c|}{ Concentration (g per $100 \mathrm{~g}$ fresh weight) } & & \\
\hline & \multicolumn{2}{|c|}{ Glucose } & \multicolumn{2}{|c|}{ Fructose } & \multicolumn{2}{|c|}{ Sucrose } & \multicolumn{2}{|c|}{ Sugars analysed } \\
\hline & 1996 & 1997 & 1996 & 1997 & 1996 & 1997 & 1996 & 1997 \\
\hline \multicolumn{9}{|l|}{ Harvest time } \\
\hline I & $0.7 \mathrm{a}$ & $0.7 \mathrm{a}$ & $0.2 \mathrm{a}$ & $0.2 \mathrm{a}$ & $0.7 \mathrm{a}$ & $0.8 \mathrm{a}$ & $1.7 \mathrm{a}$ & $1.7 \mathrm{a}$ \\
\hline II & $0.4 \mathrm{~b}$ & $0.2 \mathrm{~b}$ & $0.2 \mathrm{a}$ & $0.0 \mathrm{~b}$ & $1.2 \mathrm{~b}$ & $0.9 \mathrm{a}$ & $1.8 \mathrm{a}$ & $1.1 \mathrm{~b}$ \\
\hline III & $0.2 \mathrm{c}$ & $0.1 \mathrm{~b}$ & $0.1 \mathrm{~b}$ & $0.0 \mathrm{~b}$ & $0.9 \mathrm{c}$ & $0.4 \mathrm{~b}$ & $1.2 \mathrm{~b}$ & $0.5 \mathrm{c}$ \\
\hline \multicolumn{9}{|l|}{$\mathrm{kg} \mathrm{N} \mathrm{ha}^{-1}$} \\
\hline 60 & $0.5 \mathrm{a}$ & $0.3 \mathrm{a}$ & $0.1 \mathrm{a}$ & $0.1 \mathrm{a}$ & $0.9 \mathrm{a}$ & $0.7 \mathrm{a}$ & $1.5 \mathrm{a}$ & $1.1 \mathrm{a}$ \\
\hline 120 & $0.5 \mathrm{a}$ & $0.3 \mathrm{a}$ & $0.2 \mathrm{~b}$ & $0.1 \mathrm{a}$ & $0.9 \mathrm{a}$ & $0.7 \mathrm{a}$ & $1.6 \mathrm{a}$ & $1.1 \mathrm{a}$ \\
\hline \multicolumn{9}{|l|}{ Cultivar } \\
\hline Timo & $0.5 \mathrm{a}$ & $0.3 \mathrm{a}$ & $0.1 \mathrm{a}$ & $0.1 \mathrm{a}$ & $1.0 \mathrm{a}$ & $0.9 \mathrm{a}$ & $1.6 \mathrm{a}$ & $1.3 \mathrm{a}$ \\
\hline Gloria & $0.6 \mathrm{~b}$ & $0.4 \mathrm{~b}$ & $0.2 \mathrm{~b}$ & $0.1 \mathrm{a}$ & $1.0 \mathrm{a}$ & $0.7 \mathrm{~b}$ & $1.8 \mathrm{~b}$ & $1.2 \mathrm{~b}$ \\
\hline Van Gogh & $0.4 \mathrm{~b}$ & $0.2 \mathrm{c}$ & $0.1 \mathrm{a}$ & $0.1 \mathrm{a}$ & $0.8 \mathrm{~b}$ & $0.5 \mathrm{c}$ & $1.3 \mathrm{c}$ & $0.8 \mathrm{c}$ \\
\hline
\end{tabular}

$0.160)$ and sucrose content $(\mathrm{P}<0.467)$ resulting from different rates of nitrogen application were established (Table 7). The content of reducing sugars, in particular glucose was lower later in the growing season. Similarly, the lowest tuber sucrose contents were for the last harvest date. Significant differences in glucose $(\mathrm{P}<0.001)$, fructose $(\mathrm{P}<0.001)$ and sucrose $(\mathrm{P}<0.001)$ content among cultivars were recorded. The lowest contents of sucrose and glucose were recorded in cultivar Van Gogh (Table 7). Only the content of sucrose $(\mathrm{P}<$ $0.006)$ and total sugars analysed $(\mathrm{P}<0.014)$ varied greatly depending on year, being lowest in 1997.

\section{Discussion}

The results indicated that first early potatoes can be successfully grown under fleece in 55-60 days in southern Finland. Low temperatures during early summer, however, may lead to delay in emergence and reduced tuber growth rate, resulting in low dry matter content. Long day conditions of early summer, with light periods of 20-24 hours, are not critical because negative effects of long photoperiod on initial growth and tuber onset are not constant at low growing temperatures when 
there is large diurnal variation (Lorenzen and Ewing 1990, Van Dam et al. 1996).

The long period between planting and emergence resulted from low temperatures after planting even if pre-sprouted seed starts to grow early when soil temperatures are around $+6-8^{\circ} \mathrm{C}$ (O'Brien et al. 1983). Nitrogen fertilizer application rate did not affect duration of this period, when the transfer of nutrients from the mother tuber greatly influences growth of the emerging plant. A nitrogen supply of $60 \mathrm{~kg} \mathrm{ha}^{-1}$ was not adequate for initial development of the crop, resulting in lower LAI at low soil temperatures. Increased supply of nitrogen generally stimulated production of more branches at the top of the plant, resulting in more leaves per plant and increased LAI. In 1996 LAI was low when cool weather retarded post-emergence growth of the crop. The numbers of main stems and number of tubers per hill were similar in all plots. When seed is presprouted early the numbers of stems and tubers per hill remain low and typical differences between genotypes are not evident (Varis 1973, O'Brien et al. 1983). Also, within the broad range of commercial application rates the effect of nitrogen on the total number of stems and tubers is small.

In this study nitrogen applied at $120 \mathrm{~kg} \mathrm{ha}^{-1}$ increased yield during both trial years and at all the harvest dates. In addition, all three cultivars reacted similarly to the nitrogen application. High nitrogen application rate primarily increased soil cover development in the crop and probably affected the amount of solar radiation that was intercepted during initial development of the crop. The faster the crop canopy develops and soil is covered, the more radiation is absorbed by the crop and the higher the yield. On the other hand, oversupply of nitrogen during early growth stages causes excessive growth of the foliage, resulting in too large a canopy for optimal yield development (Krauss 1978, Vos and Biemond 1992, Kuisma 1995). Nitrogen itself has little effect on the amount of dry matter produced per unit of intercepted solar radiation (Millard and Marshall 1986). The slower canopy development of crops under low nitrogen supply can be explained mainly through reduced efficiency of fertilizer use and decline in supply of nitrogen to the crops under cool weather conditions. Potato plants grown under a wide range of nitrogen application rates generally show quite small changes in early canopy development (Vos 1997, O'Brien et al. 1998). Due to the increased quantity of radiation intercepted, high levels of applied nitrogen increased crop yield at all harvests. However, the highest yield increase, $7.2 \mathrm{t} \mathrm{ha}^{-1}$, was reached at the third harvest date. There were statistically significant first order cultivar $\times$ year and cultivar $\times$ harvest date interactions. Timo probably allocated a higher proportion of its dry matter to tubers and produced the highest yield not only at the first harvest date, but also at the remaining harvest dates. Timo has been the most popular first early cultivar in Finland for a long time.

High rates of nitrogen application increased total yield through increased solar radiation interception, and also increased tuber size, thereby increasing yield of larger grade and reducing numbers of smaller grade tubers. The effect of nitrogen on tuber size differed according to trial year. Increase in tuber size was much greater in 1997 than under the cool weather conditions of 1996. Tuber size distribution significantly affects marketable yield at the first harvest date. Timo has few tubers and produces most yield as marketable tubers.

The lower dry matter content of crops that received $120 \mathrm{~kg} \mathrm{~N} \mathrm{ha}^{-1}$ and differences between cultivars can probably be explained through decreased amount of dry matter translocated to tubers. In Norway Riley (2000) and in Sweden Carlsson (1979) reported a similar decrease of dry matter content of early potatoes when nitrogen supply was increased. Tuber dry matter concentration was higher in 1997, possibly because of the more advanced developmental stage of the plants. Timo was an example of first early potato with genetically low dry matter content. Differences in cultivar performance in dry matter content were consistent with the harvest dates and the trial years.

The range in nitrate content of tubers ranged between 13 and $189 \mathrm{mg} \mathrm{kg}^{-1}$ fresh weight. High nitrate values in 1996 were caused by retarded nitrogen metabolism of plants and delayed development of the crop under cool, relatively dry weather conditions. Plants grown with $120 \mathrm{~kg} \mathrm{~N} \mathrm{ha}^{-1}$ were 
Vol. 13 (2004): 390-398.

able to take up nitrate at high levels and store the nitrate in the vacuoles until required. Application of $60 \mathrm{~kg} \mathrm{~N} \mathrm{ha}^{-1}$ resulted in a lower nitrate concentration in tubers already during early crop growth stages. The decline in concentration of nitrate occurred as the growth stage and the harvest time progressed. The change in nitrate concentration also reflected the increase of structural and storage material in the tuber, which was associated with low nitrogen concentration (Kolbe 1987). The response of cultivars may have been influenced by genotypic features such as the stage of development of the crop and nitrogen metabolism. Early cultivars generally used to contain higher concentration of nitrate in tubers than late genotypes (Wustman et al. 1996).

Shortly after tuber initiation both sucrose and reducing sugars, fructose and glucose, contents of tubers were at high levels and then progressively declined, more rapidly for reducing sugars than sucrose, as the season advanced. Sugar content tends to be high during early growth stages because sugars are produced in large quantities by photosynthesis and transported as sucrose to tubers where they are converted to glucose and fructose for starch formation. The content of reducing sugars was also increased by climatic conditions, particularly low temperatures in 1996. In addition, cultivars differed considerably in initial contents of reducing sugars and sucrose. As observed by Mawson and Cunnington (1996), high sugar content is related to the slightly sweet flavour and aroma of early potatoes.

In conclusion, early potatoes can be successfully grown under fleece in 50-60 days in southern Finland. Because tuber yield in a short growing season is affected mainly by the intercepted radiation, methods to increase tuber yield need to address reducing the time to emergence, improving haulm growth after emergence and increasing the harvest index. Emergence will be earlier with sufficiently presprouted seed tubers and tubers of advanced physiological age (Varis 1973, O'Brien et al. 1983, Firman et al. 1992). Application of high rates of nitrogen fertilizer increases crop cover development, but may cause excessive growth of the foliage at the expense of tuber yield, resulting in low harvest index, low dry matter content and high nitrate content.

\section{References}

Aura, E. 1985. Avomaan vihannesten veden ja typen tarve. Maatalouden tutkimuskeskus, Tiedote 7/1985. 61 p.

Biemond, H. \& Vos, J. 1992. Effects of nitrogen on the development and growth of the potato plant. 2. The partitioning of dry matter, nitrogen and nitrate. Annals of Botany 70: 37-45.

Blom-Zandstra, M. 1989. Nitrate accumulation in vegetables and its relation to quality. Annals of Applied Biology 115: 553-561.

Carlsson, H. 1979. Färskpotatisens kvalitet. Rapport 76. Uppsala: Sveriges Lantbruksuniversitet. $29 \mathrm{p}$.

Firman, D.M., O’Brien, P.J. \& Allen, E.J. 1992. Predicting the emergence of potato sprouts. Journal of Agricultural Science 118: 55-61.

Haila, K., Kumpulainen, J., Häkkinen, U. \& Tahvonen, R. 1992. Sugar and organic acid contents of vegetables consumed in Finland during 1988-1989. Journal of Food Composition and Analysis 5: 100-107.

Kolbe, H. 1987. Untersuchungen zur Bedeutung des Nitratgehaltes in Kartoffelknollen. Der Kartoffelbau 38: 105106.

Krauss, A. 1978. Tuberization and abscisic acid content in Solanum tuberosum as affected by nitrogen nutrition. Potato Research 21: 183-193.

Kuisma, P. 1995. Perunan typpilannoitus vaatii taitoa. Tuottava Peruna 22: 19-23.

Li, B.W. \& Schuhmann, P.J. 1980. Gas-liquid chromatographic analysis of sugars in ready-to-breakfast cereals. Journal of Food Science 45: 138-141.

Littell, R.C., Milliken, G.A., Stroup, W.W. \& Wolfinger, R.D. 1996. SAS system for mixed models. Cary, NC, USA: SAS Institute Inc. 633 p.

Lorenzen, J.H. \& Ewing, E.E. 1990. Changes in tuberization and assimilation partitioning in potato (Solanum tuberosum L.) during the first 18 days of photoperiod treatment. Annals of Botany 66: 457-464.

Mawson, K. \& Cunnington, A. 1996. Storage of potatoes with unset skins for improved marketing opportunities. In: The 13th Triennial Conference of the European Association for Potato Research, Veldhoven the Netherlands. Abstracts of conference papers, posters and demonstration. p. 107-108.

Millard, P. \& Marshall, B. 1986. Growth, nitrogen uptake, partitioning within the potato (Solanum tuberosum L.) crop, in relation to nitrogen application. Journal of Agricultural Science 107: 421-429.

O’Brien, P.J., Allen, E.J., Bean, J.N., Griffith, R.L., Jones, S.A. \& Jones, J.L. 1983. Accumulated day-degrees as a measure of physiological age and the relationships with growth and yield in early potato cultivars. Journal of Agricultural Science 101: 613-631. 
Mustonen, L. Yield formation of early potatoes during a short growing period

O'Brien, P.J., Allen, E.J. \& Firman, D.M. 1998. A review of some studies into tuber initiation on potato (Solanum tuberosum L.) crops. Journal of Agricultural Science 130: 251-270.

Riley, H. 2000. Level and timing of nitrogen fertilizer application to early and semi-early potatoes (Solanum tuberosum L.) grown with irrigation on light soils in Norway. Acta Agriculture Scandinavica 50: 122-134.

ORION 1983. Guide to ion analysis. Massachusetts. 45 p.

Tukey, J.W. 1977. Exploratory data analysis. Reading, MA: Addison-Wesley. $688 \mathrm{p}$.

Van Dam, J., Kooman, P.L. \& Struik, P.C. 1996. Effects of temperature on early growth and final numbers of tubers in potato. Potato Research 39: 51-62.

Varis, E. 1973. The effects of tuber size and chitting method on the growth and yield of Amyla and Barima potatoes.
Journal of the Scientific Agricultural Society of Finland 45: 297-318.

Vos, J. 1997. The nitrogen response of potato (Solanum tuberosum L.) in the field: nitrogen uptake and yield, harvest index and nitrogen concentration. Potato Research 40: 237-248.

Vos, J. \& Biemond, H. 1992. Effects of nitrogen on the development and growth of the potato plant. 1. The leaf appearance, expansion growth, life spans of leaves and stem branching. Annals of Botany 70: 27-35.

Wustman, R., Geersing, J.-E., Hartsema, O. \& van der Berg, W. 1996. Variation in nitrate content of potato tubers. In: The 13th Triennial Conference of the European Association for Potato Research, Veldhoven the Netherlands. Abstracts of conference papers, posters and demonstration. p. 232-233.

\title{
SELOSTUS
}

\section{Typpilannoituksen ja nostoajankohdan vaikutus varhaisperunan satoon}

\author{
Leo Mustonen \\ MTT (Maa- ja elintarviketalouden tutkimuskeskus)
}

\begin{abstract}
Kaksivuotisessa kokeessa 1996-1997 tutkittiin typpilannoituksen ja nostoajankohdan vaikutusta varhaisperunan sadon kehitykseen, määrään ja laatuun. Kokeet järjestettiin Maa- ja elintarviketalouden tutkimuskeskuksessa Jokioisissa. Vertailussa olivat typpilannoitusmäärät 60 ja 120 kg/ha sekä kolme nostoajankohtaa. Lajikkeet olivat Timo ja Gloria sekä aikainen talviperuna Van Gogh.

Typpilannoitus ei nopeuttanut perunan taimelle tuloa, mutta myöhemmin $120 \mathrm{~kg} / \mathrm{ha}$ typpilannoitus nopeutti perunan kehitystä ja lisäsi kasvuston lehtipintaalaa. Suuri typpimäärä lisäsi varhaisnoston satoa $0,5-2,5$ t/ha. Sadoltaan paras lajike oli Timo. Typpilannoitus vaikutti sadon määrään eniten kolmantena nostoajankohtana elokuun alussa, jolloin sadonlisäys oli 3,0-6,2 t/ha. Varhaissadon kuiva-ainepitoisuus oli pieni 13,8-17,2\%. Suuri typpimäärä pienensi mukuloiden kuiva-ainepitoi-
\end{abstract}

suutta $0,3-1,0 \%$. Typpilannoitus suurensi selvästi sadon mukulakokoa ja kauppakelpoisen sadon määräa. Typen lisääminen lisäsi selvästi perunan nitraattipitoisuutta. Mukuloiden nitraattipitoisuus vaihteli $13-189$ mg NO${ }_{3} /$ kg. Nitraattipitoisuus ei kuitenkaan ylittänyt suurinta hyväksyttävää pitoisuutta $200 \mathrm{mg} \mathrm{NO} / \mathrm{kg}$ tuorepainossa. Typpilannoitus ei vaikuttanut mukuloiden sokeripitoisuuteen. Perunan sokeripitoisuus oli suurin varhaissadossa ja pieneni voimakkaasti myöhempinä nostoajankohtina.

Typpilannoituksen lisäys nopeutti varhaisperunan varsiston kehitystä ja lisäsi mukulasatoa. Runsas typpilannoitus voi kuitenkin lisätä voimakkaasti varsiston kasvua sadon kustannuksella ja samalla viivästyttää sadon ja kuiva-ainepitoisuuden kehitystä sekä heikentää perunan laatua. 